\title{
В.А. Потабаиній
}

\section{НОВИЙ ПІДХІД ДО ВИЗНАЧЕННЯ ГЕОМЕТРІЇ ЛІВОГО ШЛУНОЧКА ПРИ ХРОНІЧНІЙ СЕРЦЕВІЙ НЕДОСТАТНОСТІ У ХВОРИХ НА АГ ТА ІХС У ПОСДНАННІ 3 ХОЗЛ}

\author{
Д3 «Дніпропетровська медична академія МОЗ України» \\ кафедра терапії, кардіологї та сімейної медииини ФПО \\ (зав. - д. мед. н., проф. В.А. Потабашній) \\ вул. Дзержинського, 9, Дніпропетровськ, 49044, Україна \\ $S E$ «Dnipropetrovsk medical academy of Health Ministry of Ukraine» \\ Department of therapy, cardiology and family medicine \\ Dzerzhinsky str., 9, Dnipropetrovsk, 49044, Ukraine \\ e-mail:dsma@dsma.dp.ua
}

Ключові слова: хронічна сериева недостатність, артеріальна гіпертензія, ішемічна хвороба серия, хронічне обструктивне захворювання легень, геометрія лівого шлуночка

Key words: chronic heart failure, arterial hypertension, ischemic heart disease, chronic obstructive pulmonary disease, geometry of left ventricle

Реферат. Новый подход к определению геометрии левого желудочка при хронической сердечной недостаточности у больных с АГ и ИБС в сочетании с ХОЗЛ. Потабашний В.А. Целью исследования было определение направлений изменения геометрии левого желудочка (ЛЖ) при ХСН у больньх артериальной гипертензией (АГ), ИБС и ХОБЛ в зависимости от выраженности клинических признаков ХСН и тяжести ХОБЛ согласно рекомендациям Американского общества по эхокардиографии и Европейской ассоицации по визуализации сердия (2015). Мы обследовали 67 больных с ХСН, ассоциированной с АГ и стабильной ИБС в сочетании со стабильной ХОБЛ. В результате исследования выявили различнье типь геометрии ЛЖ: концентрическую гипертрофию ЛЖ (ГЛЖ), эксиентрическую ГЛЖ, смешанную ГЛЖ, дилатационную ГЛЖ, развитие которых зависит от уровня артериального давления, фиброзных и ишемических изменений миокарда, первичной доминирующей болезни - АГ, ИБС или ХОБЛ.

\begin{abstract}
Novel approach for identification of left ventricle geometry in patients with chronic heart failure, AH and IHD in combination with COPD. Potabashniy V.A. The aim of this study was to examine the direction of change of left ventricle $(\mathrm{LV})$ geometry in patients with chronic heart failure (CHF), arterial hypertension (AH) and ischemic heart disease (IHD) in combination with chronic obstructive pulmonary disease (COPD) in dependence on severity of clinical signs of CHF and COPD based on recommendation of American Society of Echocardiography and European Association of Cardiovascular Images (2015). We examined 67 patients with CHF, associated with AH and stable IHD and stable COPD. By the results of this study there were determined different types of left ventricle geometry: concentric LV hypertrophy $(L V H)$, eccentric LVH, mixed LVH, dilated LVH, dependent on blood pressure level, fibrosic and ischemic myocardial changes, primary predominant disease - AH, IHD or COPD.
\end{abstract}

У реальній клінічній практиці визначальне місце посідає коморбідна патологія, що вносить певні особливості в перебіг та труднощі в діагностиці й лікуванні окремих нозологій при їх поєднанні [1]. Останнім часом привертає увагу поєднання патології серцево-судинної i дихальної систем. В Україні, як і в країнах Заходу, артеріальна гіпертензія (АГ), ішемічна хвороба серця (IXC) i серцева недостатність (CH) $\epsilon$ найбільш поширеними причинами захворюваності і смертності [9, 26]. Хронічне обструктивне захворювання легень (ХОЗЛ) посідає третє місце серед найбільш частих причин смертності [15]. Хвороби серцево-судинної системи (ХСС) і ХОЗЛ мають спільні фактори ризику - паління i системне запалення, що зокрема пояснює часте поєднання цих патологій [15]. Поєднання АГ, IXC i ХОЗЛ негативно впливає на довготривалий прогноз [21]. IXC, включаючи інфаркт мікарда (IM), є поширеною причиною смерті у пацієнтів 3 ХОЗЛ [15], поступаючись лише загостренням ХОЗЛ [18]. Важливість розробки підходів до ведення пацієнтів 3 кардіореспіраторними коморбідними станами відображена в сучасній класифікації ХОЗЛ, в якій передбачається обов'язкова оцінка поєднаної патології, передусім серцево-судинної [2]. Поширеними є поєднання ХОЗЛ і АГ. В середньому АГ зустрічається у пацієнтів з ХОЗЛ у 34,3\% [2]. При IM перкутанні коронарні втручання на тлі ХОЗЛ супроводжуються меншою короткочасною i довготривалою 
виживаністю $[8,17]$. Затримка в діагностиці IM, використанні коронарографії, часі та проведенні реперфузії, а також застосуванні ліків для вторинної профілактики $є$ потенціальними чинниками, які пояснюють більш високу смертність після ІМ у пацієнтів 3 ХОЗЛ [25]. ХОЗЛ асоційоване зі зростанням ризику раптової серцевої смерті. Особливо зростає ризик у пацієнтів 3 частими загостреннями протягом 5 років після діагностування ХОЗЛ. Це є новим індикатором, що вказує на необхідність дій щодо попередження раптової серцевої смерті [19]. Прямим гемодинамічним наслідком ХОЗЛ є хронічне легеневе серце [7]. Однак залучення серцево-судинної системи при ХОЗЛ $є$ більш складним [16]. Більшість пацієнтів з ХОЗЛ помирає через $\mathrm{CH}$, ніж від дихальної недостатності [7]. Ризик серцево-судинних ускладнень при ХОЗЛ збільшується в 4,98 разу, а інсультів - у 3,34 разу [22].

Супутня СН діагностується у $20 \%$ пацієнтів 3 ХОЗЛ, яка майже в половині випадків має систолічну дисфункцію ЛШ. Серед пацієнтів 3 СН поширеність ХОЗЛ досягає 35\%, яке менше ніж у $25 \%$ відповідає III-IV стадії за класифікацією GOLD [20]. Більш тяжке ХОЗЛ спостерігається у випадках $\mathrm{CH}$ зі збереженою ФВ ЛШ [20]. При співіснуванні СН і ХОЗЛ ризик смерті зростає на 39\% [20]. У дослідженні European Heart Failure Pilot Survey поширеність ХОЗЛ серед пацієнтів з $\mathrm{CH}$ становила $15 \%$. Спостерігалася тенденція до збільшення смертності на $37 \%$ порівняно з такою при відсутності ХОЗЛ. Частота СН зі зниженою і збереженою ФВ ЛШ відрізнялася недостовірно [12]. У дослідженні Cardiovascular Health Study встановлено, що у пацієнтів похилого віку з $\mathrm{CH}$ найвищий ризик смерті спостерігається у випадках поєднання систолічної дисфункції ЛШ з порушенням легеневої функції. Тому в такого контингенту у випадках $\mathrm{CH}$ слід визначати також стан легеневої функції [10]. За даними Worcester Heart Failure Study, 35,9\% госпіталізованих пацієнтів 3 гостро декомпенсованою $\mathrm{CH}$ мали в анамнезі ХОЗЛ. Серед пацієнтів 3 ХОЗЛ, які були виписані з госпіталю, смертність протягом 1 і 5 років на $10 \%$ i $40 \%$ перевищувала таку у пацієнтів без ХОЗЛ відповідно [13]. ХОЗЛ часто зустрічається у пацієнтів з $\mathrm{CH}$ як зі зниженою, так і збереженою ФВ ЛШ, а в більшості випадків залишається недіагностованою. У пацієнтів з $\mathrm{CH}$ потрібен скринінг на наявність ХОЗЛ у стабільну фазу перебігу [11]. Таким чином, ХОЗЛ є вірогідним і незалежним предиктором смертності при СН як зі зниженою, так і збереженою ФВ ЛШ [3].
Структурно-функціональні зміни серця, зокрема лівого шлуночка (ЛШ), є основою ремоделювання серця, тому визначення геометрії ЛШ має важливе значення як у діагностиці, так i у виборі напрямку лікування. Класичний підхід до стратифікації геометрії ЛШ включає критерії концентричного ремоделювання, концентричної та ексцентричної гіпертрофії ЛШ. Останнім часом запропоновано більш ретельний підхід до стратифікації геометрії ЛШ у пацієнтів з АГ [14, 24].

Метою дослідження було визначення напрямків зміни геометрії ЛШ у пацієнтів 3 АГ і стабільною IXC у поєднанні з ХОЗЛ залежно від вираженості клінічних ознак ХCH і тяжкості ХОЗЛ згідно з рекомендаціями Американського товариства 3 ехокардіографії та Європейської асоціації 3 візуалізації серця Європейського кардіологічного товариства (2015) [24].

\section{МАТЕРІАЛИ ТА МЕТОДИ ДОСЛІДЖЕНЬ}

До дослідження увійшло 67 пацієнтів 3 АГ, стабільною IXC у поєднанні з ХОЗЛ. Чоловіків було 45 (67,1\%), а жінок - 22 (32,9\%). Середній вік становив $63,4 \pm 10,1$ року. Критерії виключення 3 дослідження включали активну ішемію міокарда за клініко-ЕКГ даними, аневризми лівого шлуночка (ЛШ), асиметричну гіпертрофію ЛШ (ГЛШ) та загострення ХОЗЛ. Усі пацієнти дали згоду на проведення дослідження. Діагностику АГ проводили за Наказом МО3 України № 284 від 2012 року [4]. АГ 1 ступеня діагностована в $10(15,0 \%)$ хворих, 2 ступеня - в $48(71,6 \%)$ і 3 ступеня - в 9 (13,4\%). АГ ІІ стадії мала місце в 51 (76,1\%) і ІІІ стадії - в 16 (23,9\%). Стабільну IXC діагностували відповідно до Наказу МОЗ України № 152 від 02.03.2016 року [5]. Стенокардія напруження мала місце в 55 $(82,1 \%)$ випадках, яка у $39(70,9 \%)$ була типовою і в $16(29,1 \%)$ - атиповою. Безбольова форма IXC виявлена в 12 (17,9\%) хворих. У клінічній картині переважна симптоматика IXC виявлена у 48 (71,6\%) хворих, з них у 31 (64,6\%) були ознаки хронічної серцевої недостатності (XCH) II-A стадії. У 17 (35,4\%) випадках не було клінічних ознак ХCH, але через наявність дисфункції ЛШ за даними ЕхоКГ вони віднесені до ХСН І стадії. Переважна симптоматика ХОЗЛ і ознаки ХCH правошлуночкового типу (ПШН) мали місце в 10 $(14,9 \%)$ хворих. У $9(13,5 \%)$ випадках діагностована ХCH ІІ-Б стадії, клінічна симптоматика відповідала сполученому захворюванню без чіткого переважання ураження серця або легень. Діагностику i стратифікацію тяжкості ХОЗЛ виконували згідно 3 Наказом МО3 України № 555 від 2013 року [6]. Обов'язковим було спірометричне підтвердження ХОЗЛ. Переважна 
більшість чоловіків палила протягом багатьох років, у середньому 20 пачко-років. Пацієнтів 3 ХОЗЛ розподіляли на 4 групи $(\mathrm{A}, \mathrm{B}, \mathrm{C}, \mathrm{D})$, а кожну групу поділяли за рівнем тяжкості бронхіальної обструкції згідно з класифікацією GOLD та ризиком загострень. ХОЗЛ 4 ступеня встановлено у $30(44,8 \%)$, 3 них у групі «С» -17 , а в групі «D»-13. До ХОЗЛ 3 ступеня віднесено $31(46,3 \%)$ пацієнта, 3 яких у групі «С» було 14 , a в групі «D» - 17. ХОЗЛ 2 ступеня виявлено лише в $6(8,9 \%)$ хворих, які відповідали групі «В». Розподіл хворих залежно від вираженості ХCH і ХОЗЛ відображено в таблиці 1.

Табличяя 1 .

Розподіл пацієнтів основної групи залежно від вираженості ХСН і ХОЗЛ

\begin{tabular}{|c|c|c|c|c|c|c|}
\hline \multirow{2}{*}{ Стадія ХСН } & \multicolumn{2}{|c|}{$\begin{array}{c}\text { ХОЗЛ гр. В } \\
(n=6)\end{array}$} & \multicolumn{2}{|c|}{$\begin{array}{c}\text { ХОЗЛ гр. С } \\
(n=14)\end{array}$} & \multicolumn{2}{|c|}{$\begin{array}{c}\text { ХОЗЛ гр.D } \\
(n=17)\end{array}$} \\
\hline & GOLD 1 & GOLD 2 & GOLD 3 & GOLD 4 & GOLD 3 & GOLD 4 \\
\hline I $(n=17)$ & - & 6 & 7 & 1 & 3 & - \\
\hline II-A $(n=31)$ & - & & 7 & 9 & 8 & 7 \\
\hline ПШН (n=10) & - & & - & 5 & 3 & 2 \\
\hline II-Б (n=9) & - & & - & 2 & 3 & 4 \\
\hline Всього & 0 & 6 & 14 & 17 & 17 & 13 \\
\hline
\end{tabular}

Пр и м і т к а . ПШН - правошлуночкова недостатність

ЕхоКГ виконували на апараті "Sonos-1000" фiрми Hewlett Packard за допомогою механічного датчика потужністю 3,5 Мгц 3 одночасним записом ЕКГ. Визначення діастолічних лінійних i об'ємних розмірів ЛШ та типів геометрії ЛШ виконували згідно 3 рекомендаціями Американського товариства 3 ехокардіографії (АТЕ) та Європейської ехокардіографічної асоціації (СЕА) 2015 року [24, 23]. Використовували новий під- хід до стратифікації геометрії ЛШ, що відображено на рисунку. Відносну товщину стінки ЛШ (ВТСЛШ) розраховували за відношенням суми діастолічних товщин міжшлуночкової перегородки (Тмшп) і задньої стінки ЛШ (Тзслш) до кінцево-діастолічного розміру ЛШ (КДРлш). Масу ЛШ, яку індексували до площі поверхні тіла (ІМЛШ), розраховували за формулою: МЛШ (г)=1,04x(КДРІ+МЖП+3СЛШ $)^{3} \mathrm{x} 0,8+0,6$.

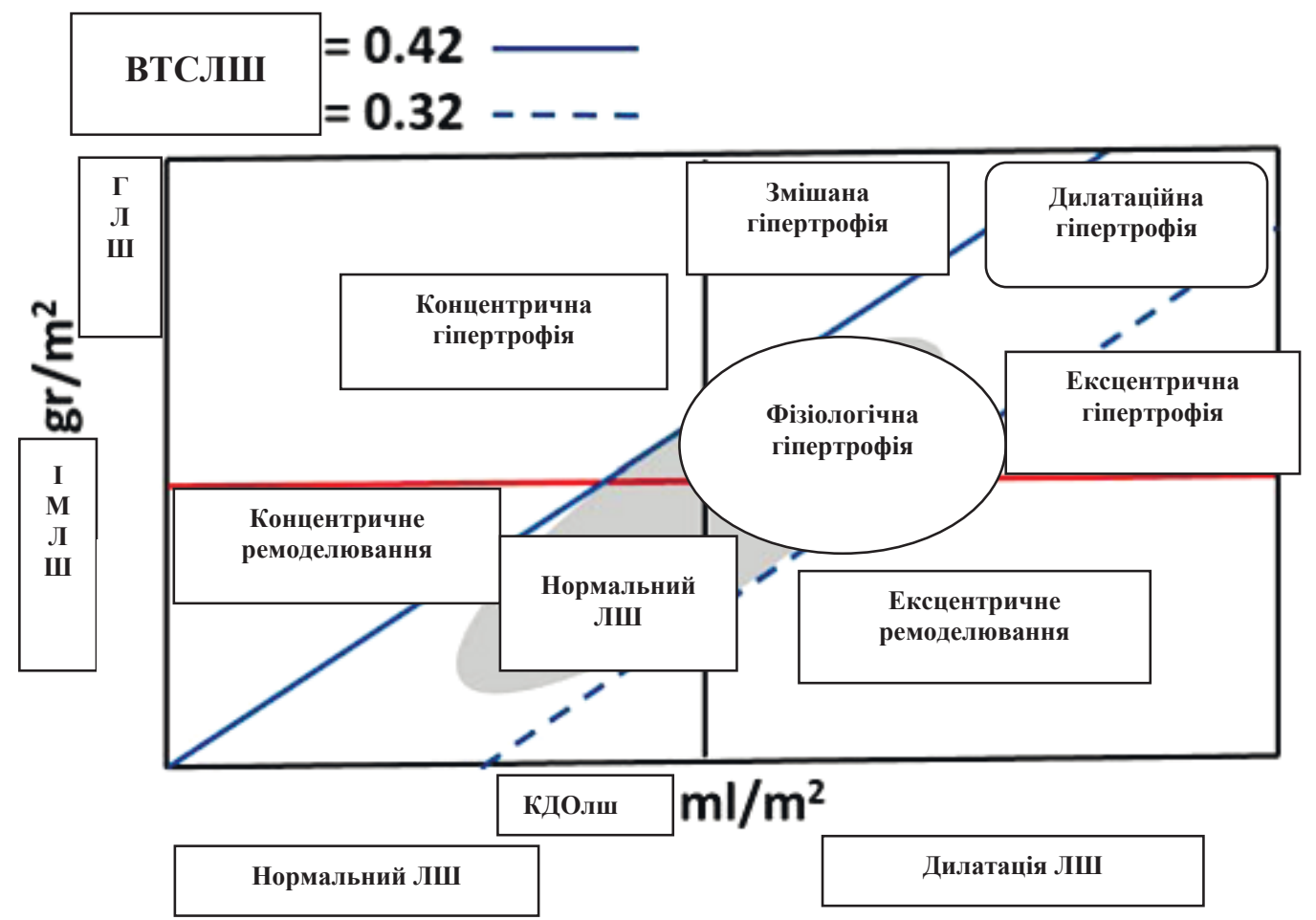

Умовні позначки: ВТСЛШ - відносна товщина стінки ЛШ; ГЛШ - гіпертрофія ЛШ; ІМЛШ - індекс маси ЛШ.

Стратифікація геометрії лівого шлуночка 
Для характеристики вираженості змін КДОІ, ІМЛШ і ВТСЛШ залежно від статі використо- вували таблиці 2. Типи геометрії ЛШ визначали за критеріями, відображеними в таблиці 3.

Градація КДОІ, ІМЛШ та ВТСЛШ залежно від статі згідно з рекомендаціями Американського товариства з ехокардіографії та Європейської асоціації з візуалізації серця (2015)

\begin{tabular}{|c|c|c|c|c|}
\hline 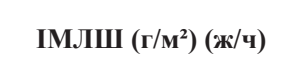 & Норма & $\begin{array}{c}\text { Незначне } \\
\text { збільшення }\end{array}$ & $\begin{array}{c}\text { Помірне } \\
\text { збільшення }\end{array}$ & $\begin{array}{c}\text { Виражене } \\
\text { збільшення }\end{array}$ \\
\hline Жінки & 43-95 & 96-108 & 109-121 & $\geq 122$ \\
\hline Чоловіки & 49-115 & $116-131$ & $132-148$ & $\geq 149$ \\
\hline \multicolumn{5}{|l|}{ ВТСЛШ (ум.од.) (ж/ч) } \\
\hline Жінки & $0,22-0,42$ & $0.43-0.47$ & $0,48-0,52$ & $\geq \mathbf{0 , 5 3}$ \\
\hline Чоловіки & $0,24-0,42$ & $0.43-0.46$ & $0,47-0,51$ & $\geq 0,52$ \\
\hline \multicolumn{5}{|l|}{ КДОІ (мл/м²) (ж/ч) } \\
\hline Жінки & $29-61$ & $62-70$ & $71-80$ & $>\mathbf{8 0}$ \\
\hline Чоловіки & $34-74$ & $75-89$ & $90-100$ & $>100$ \\
\hline
\end{tabular}

П р и м і т к а . КДОІ - індекс кінцево-діастолічного об’єму ЛШ.

Математико-статистичний аналіз результатів дослідження проводили за допомогою ліцензійної програми STATISTICA (версія 6.1), серійний номер AGAR 909 E415822FA $з$ розрахуван- ням середніх величин (M), середньо-квадратичного відхилення (SD), помилки середньої величини (m). Результати представлено як $\mathrm{M} \pm \mathrm{SD}$. За достовірні відмінності приймали величину $\mathrm{p}<0,05$.

Таблиця 3

Критерії діагностики типів геометрії ЛШ згідно з рекомендаціями Американського товариства з ехокардіографії та Європейської асоціації з візуалізації серця (2015)

\begin{tabular}{|c|c|c|c|}
\hline Типи геометрії ЛШ & $\begin{array}{c}\text { КДОІ } \\
\left(\mathbf{M л} / \mathbf{M}^{2}\right)\end{array}$ & $\begin{array}{c}\text { ІМЛШІ } \\
\left(\mathbf{r} / \mathbf{M}^{2}\right)\end{array}$ & $\begin{array}{c}\text { ВТСЛШ } \\
\text { (ум.од) }\end{array}$ \\
\hline Нормальний ЛШ & $\leq 75$ & $\begin{array}{l}\leq 115 \text { (ч) } \\
\leq 95 \text { (Ж) }\end{array}$ & $0,32-0,42$ \\
\hline Фізіологічна ГЛШ & $>75$ & $\begin{array}{l}>115 \text { (ч) } \\
>95 \text { (Ж) }\end{array}$ & $0,32-0,42$ \\
\hline Концентричне ремоделювання ЛШ & $\leq 75$ & $\begin{array}{l}\leq 115 \text { (ч) } \\
\leq 95 \text { (ж) }\end{array}$ & $>\mathbf{0 , 4 2}$ \\
\hline Ексцентричне ремоделювання ЛШ & $\geq 75$ & $\begin{array}{l}\leq 115 \text { (ч) } \\
\leq 95 \text { (Ж) }\end{array}$ & $>0,32$ \\
\hline Концентрична ГЛШ & $\leq 75$ & $\begin{array}{l}>115 \text { (ч) } \\
>95 \text { (Ж) }\end{array}$ & $>0,42$ \\
\hline Змішана ГЛШ & $>75$ & $\begin{array}{l}>115 \text { (ч) } \\
>95 \text { (Ж) }\end{array}$ & $>0,42$ \\
\hline Дилатаційна ГЛШ & $>75$ & $\begin{array}{l}>115 \text { (ч) } \\
>95 \text { (Ж) }\end{array}$ & $0,32-0,42$ \\
\hline Ексцентрична ГЛШ & $>75$ & $\begin{array}{l}>115 \text { (ч) } \\
>95 \text { (ж) }\end{array}$ & $<0,32$ \\
\hline
\end{tabular}




\section{РЕЗУЛЬТАТИ ТА ЇХ ОБГОВОРЕННЯ}

У таблиці 4 представлено результати аналізу діастолічних лінійних і об'ємних показників ЛШ в основній і групах порівняння. У цілому серед хворих на АГ і IXC в поєднанні з ХОЗЛ (основна група) виявлено достовірне збільшення КДОІ порівняно не лише 3 контрольною групою, а й хворими на АГ, IXC і ХОЗЛ груп зіставлення. У пацієнтів з IXC і АГ у поєднанні з ХОЗЛ середня величина ВТСЛШ становила 0,44 $\pm 0,129$.

Таблиия 4

\section{Лінійні й об'ємні діастолічні розміри лівого шлуночка в основній групі та групах порівняння (M $\pm \mathrm{SD})$}

\begin{tabular}{|c|c|c|c|c|c|}
\hline Пара-метри & $\begin{array}{c}\text { Конт-роль } \\
(\mathbf{n}=\mathbf{3 0})\end{array}$ & $\begin{array}{c}\text { АГ без ХCH } \\
(n=30)\end{array}$ & $\begin{array}{c}\text { IXC без XCH } \\
\quad(n=30)\end{array}$ & $\begin{array}{c}\text { ХОЗЛ без ХСН } \\
(n=30)\end{array}$ & $\begin{array}{c}\mathrm{A \Gamma}+\mathrm{IXC}+\mathrm{XO3Л} 3 \mathrm{XCH} \\
(\mathrm{n}=67)\end{array}$ \\
\hline КДР (см) & $4,6 \pm 0,36$ & $4,5 \pm 0,41$ & $4,6 \pm 0,32$ & $4,7 \pm 0,38$ & $5,4 \pm 0,72 *$ \\
\hline КДРІ (см/ $\left.\mathbf{M}^{2}\right)$ & $2,6 \pm 0,41$ & $2,5 \pm 0,39$ & $2,6 \pm 0,28$ & $2,6 \pm 0,31$ & $2,9 \pm 0,46$ \\
\hline КДО (мл) & $97,7 \pm 2,64$ & $94,1 \pm 8,61$ & $98,2 \pm 7,63$ & $103,4 \pm 9,07$ & $146,7 \pm 44,86^{*}$ \\
\hline КДІ (мл/м²) & $55,8 \pm 1,87$ & $52,1 \pm 4,76$ & $55,0 \pm 3,91$ & $58,4 \pm 7,49$ & $75,6 \pm 24,72 *$ \\
\hline
\end{tabular}

У таблиці 5 відображено зміни діастолічних лінійних і об'ємних розмірів ЛШ залежно від стадії ХСН. У цілому спостерігалося достовірне збільшення КДОІ порівняно з контрольною групою. Згідно $з$ даними таблиці 6, в основній групі
ІМЛШ достовірно перевищував такий як у контрольній групі, так і в групах порівняння. Однак привертає увагу великий рівень середньоквадратичного відхилення, що вказує на значну гетерогенність хворих.

Таблиия 5

\section{Лінійні й об'ємні діастолічні розміри лівого шлуночка у хворих з АГ та IXC у посднанні з ХОЗЛ у різних клінічних підгрупах ХСН (M \pm SD)}

\begin{tabular}{|c|c|c|c|c|c|c|}
\hline Параметри & $\begin{array}{c}\text { Контроль } \\
(\mathbf{n = 3 0})\end{array}$ & $\begin{array}{c}\text { ХСН І стадії } \\
(\mathbf{n}=17)\end{array}$ & $\begin{array}{c}\text { ХСН ІІ-А стадії } \\
(n=31)\end{array}$ & $\begin{array}{l}\text { ПШН } \\
(\mathbf{n}=\mathbf{1 0})\end{array}$ & $\begin{array}{c}\text { ХСН ІІ-Б стадії } \\
(\mathbf{n}=9)\end{array}$ & $\begin{array}{l}\text { У цілому по } \\
\text { групі (n=67) }\end{array}$ \\
\hline КДР (см) & $4,6 \pm 0,36$ & $5,1 \pm 0,60 *$ & $5,6 \pm 0,63^{*}$ & $4,8 \pm 0,46$ & $5,6 \pm 0,62 *$ & $5,4 \pm 0,72 *$ \\
\hline КДРІ (см/м²) & $2,6 \pm 0,41$ & $2,8 \pm 0,33$ & $\mathbf{3 , 1} \pm \mathbf{0 , 5 0}$ & $2,4 \pm 0,31$ & $3,0 \pm 0,42$ & $2,9 \pm 0,46$ \\
\hline КДО (мл) & $97,7 \pm 2,64$ & $123,1 \pm 36,88^{*}$ & $154,2 \pm 38,79 *$ & $106,7 \pm 24,83$ & $153,3 \pm 39,97 *$ & $146,7 \pm 44,86 *$ \\
\hline КДОІ (мл/м²) & $55,8 \pm 1,87$ & $69,1 \pm 19,88$ & $84,9 \pm 25,10 *$ & $52,8 \pm 8,13$ & $82,6 \pm 22,30 *$ & $75,6 \pm 24,72 *$ \\
\hline
\end{tabular}

П р и м і т к а . * - достовірна $(\mathrm{p}<0,05)$ різниця з контрольною групою.

Індивідуальний аналіз довів, що при XCH I стадії величина ВТСЛШ становила $0,47 \pm 0,121$. Виражена дилатація ЛШ з ВТСЛШ менше 0,32 (ексцентрична ГЛШ) зареєстрована у 3 випадках. У 13 (48,2\%) хворих ВТСЛШ перевищувала 0,42 при помірній дилатації ЛШ (змішана ГЛШ). В 1 випадку ВТСЛШ перевищувала 0,42 при нормальних діастолічних параметрах ЛШ (концентрична ГЛШ). Отже, у хворих на АГ та IXC у поєднанні з ХОЗЛ, особливо 2-го і 3-го ступеня за GOLD та клінічних груп В і C, переважає формування ГЛШ змішаного типу.

При ХCH II-A стадії середня величина ВТСЛШ становила 0,41 $\pm 0,171.323(76,7 \%)$ випадків з вираженою дилатацією ЛШ у 9 (39,2\%) вона супроводжувалася ВТСЛШ у межах $0,32-$ 0,42 (дилатаційна ГЛШ) і в $7(30,4 \%)$ - менше 0,32 (ексцентрична ГЛШ). У 7 (30,4\%) випадках ВТСЛШ перевищувала 0,42 (змішана ГЛШ). У 8 хворих $(23,3 \%)$ мала місце концентрична ГЛШ. 
Таким чином, у пацієнтів з XСН II-А стадії при IXC і АГ у поєднанні з ХОЗЛ виявлена широка палітра типів геометрії ЛШ 3 переважанням перебудови геометрії ЛШ у бік дилатації.
Привертає увагу те, що серед хворих цієї підгрупи ХОЗЛ відповідало виключно 3-му і 4му ступеню за GOLD і клінічним групам C i D.

Таблиия 6

Маса та індекс маси ЛШ в основній і групах порівняння

\begin{tabular}{|c|c|c|c|c|c|}
\hline \multirow{2}{*}{ Параметри } & Контроль & АГ без ХСН & IXC без ХСН & ХОЗЛ без ХСН & АГ+ІХХC+ХОЗЛ з ХСН \\
\hline & $\mathbf{n}=\mathbf{3 0}$ & $\mathbf{n}=\mathbf{3 0}$ & $\mathrm{n}=\mathbf{3 0}$ & $\mathrm{n}=\mathbf{3 0}$ & $\mathrm{n}=67$ \\
\hline МЛШ (г) & $119,6 \pm 28,9$ & $191,1 \pm 56,08 *$ & $149,6 \pm 35,72 *$ & $139,5 \pm 24,48^{*}$ & $260,2 \pm 56,33^{*}$ \\
\hline 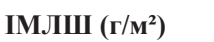 & $69,1 \pm 14,71$ & $108,6 \pm 29,15^{*}$ & $85,1 \pm 17,92 *$ & $79,3 \pm 13,76$ & $138,5 \pm 32,89^{*}$ \\
\hline
\end{tabular}

Пр и м і т к а . *- достовірна $(\mathrm{p}<0,05)$ різниця 3 контрольною групою.

У випадках з ХСН ІІ-Б стадії середня величина ВТСЛШ становила $0,42 \pm 0,110$. У $6(66,7 \%)$ випадках мала місце виражена дилатація ЛШ, 3 них у $3(50,0 \%)$ ВТСЛШ становила менше 0,32 (ексцентрична ГЛШ), а в інших 3 хворих ВТСЛШ знаходилася в межах 0,32-0,42 (дилатаційна ГЛШ). У 3 (33,3\%) хворих з відсутньою дилатацією ЛШ показник ВТСЛШ перевищував 0,42 (концентрична ГЛШ). Слід зауважити, що в цій підгрупі хворих ХОЗЛ у переважній більшості випадків $(77,8 \%)$ відповідало 3-му і 4-му ступеню за GOLD і клінічній групі D.

У пацієнтів з клінічно ізольованою правошлуночковою $\mathrm{XCH}$ (ПШН) середня величина ВТСЛШ становила $0,46 \pm 0,113$. У $6(60,0 \%)$ випадках не виявлено дилатації ЛШ, а ВТСЛШ перевищувала 0,42, тобто спостерігалася концентрична ГЛШ. У 4 хворих з дилатацією ЛШ і показником ВТСЛШ більше 0,42 діагностована змішана ГЛШ. У цій підгрупі хворих тяжкість ХОЗЛ відповідала 4-му ступеню за GOLD i клінічним групам C i D.
Проведене дослідження дозволило встановити, що напрямки зміни геометрії ЛШ при ХCH у хворих на АГ та IXC у поєднанні з ХОЗЛ різноманітні, на які зокрема впливають рівень артеріального тиску, гіпертрофія ЛШ, розвиток фіброзних та ішемічних змін у міокарді на тлі гіпоксії.

\section{ВИСНОВКИ}

1. Одним з визначних механізмів розвитку $\mathrm{i}$ прогресування XCH у хворих на АГ та IXC у поєднанні з ХОЗЛ є ремоделювання ЛШ.

2. При ХСН у хворих на АГ та IXC у поєднанні 3 ХОЗЛ спостерігається різний профіль геометрії ЛШ залежно від типу і стадії XCH, переважаючої симптоматики IXС / АГ або ХОЗЛ.

3. Застосування нового підходу до більш ретельної стратифікації напрямків ремоделювання ЛШ у такого контингенту хворих $\epsilon$ базисом для подальшого вивчення прогностичного значення окремих типів геометрії ЛШ, можливості впливу терапії на їх прогресування i несприятливий напрямок трансформації.

\section{СПИСОК ЛІТЕРАТУРИ}

1. Дзяк Г.В. Эффективность ивабрадина у пациентов с кардиореспираторной патологией / Г.В. Дзяк // Укр. пульмонол. журнал. - 2008. - № 3, додаток. - С. 55.

2. Долгушева Ю.А. $\beta$-агонисты различной длительности действия у пациентов с сочетанием сердечно-сосудистой патологии и бронхообструктивных заболеваний / Ю.А. Долгушева, К.А. Зыков, И.Е. Чазова // Практ. пульмонология. - 2015. - № 2. - С. 41-47.

3. Коваль Е.А. ХСН при коморбидных состояниях: выбор оптимального $\beta$-блокатора / Е.А. Коваль // Здоров’я України. - 2015. - № 3. - С. 19.

4. Уніфікований клінічний протокол первинної, вторинної (спеціалізованої), третинної (високоспеціа- лізованої) медичної допомоги «Артеріальна гіпертензія»: Наказ МОЗ України № 284 від 2012 року.

5. Уніфікований клінічний протокол первинної, вторинної (спеціалізованої), третинної (високоспеціалізованої) медичної допомоги «Стабільна ішемічна хвороба серця»: Наказ МО3 України № 152 від 02.03.2016.

6. Уніфікований клінічний протокол первинної, вторинної (спеціалізованої), третинної (високоспеціалізованої) медичної допомоги та медичної реабілітації «Хронічне обструктивне захворювання легень»: Наказ МО3 України від 27.06.2013 № 555. Київ, МО3 України, 2013. - 92 с. 
7. Barnes PJ. Systemic manifestations and comorbidities of COPD / P.J.Barnes, B.R.Celli // Eur. Respir. J. 2009. - Vol. 33. - P. 1165-1185.

8. Campo G. Impact of COPD on long-term outcome after ST-segment elevation myocardial infarction receiving primary percutaneous coronary intervention / G. Campo, P. Guastaroba, A. Marzocchi, A. Santarelli [et al.] // Chest.-2013. - Vol. 144. - P. 750-757.

9. Campo G. Overview of the pharmacological challenges facing physicians in the management of patients with concomitant cardiovascular disease and chronic obstructive pulmonary disease / G. Campo, R. Pavasini, S. Biscaglia, M. Contoli, C. Ceconi // Eur. Heart J. - Cardiovasc. Pharmacother. - 2015. - Vol. 1. - P. 205-211.

10. Cardiovascular and mortality outcomes in the elderly with impaired cardiac and pulmonary function: The Cardiovascular Health Study (CHS) / S. Waheed, P.H.M. Chaves, J.M. Gardin, J.J. Cao // J. Am. Heart Assoc. -2015 . - Vol. 4. - P. 1-10.

11. COPD in patients with stable heart failure in the primary care setting / M.J. Valk, B.D. Broekhuizen, A. Mosterd, N.P. Zuithoff [et al.] // Inter. J. COPD. 2015. - Vol.10. - P. 1219-1224.

12. Co-morbidities in patients with heart failure: an analysis of the European Heart Failure Pilot Survey / V.M. van Deursen, R. Urso, C. Laroche, K. Damman [et al.] // Eur. J. Heart Failure. - 2014. - Vol. 16. - P. 103-111.

13. Fisher K.A. Impact of COPD on the mortality and treatment of patients hospitalized with acute decompensated heart failure (The Worcester Heart Failure Study): A Masters Thesis / University of Massachusetts Medical School. - 2014. - GSBS Dissertations and Theses. Paper 717. http://escholarship.umassmed.edu/gsbs_diss/717

14. Gaasch W.H. Left ventricular structural remodeling in health and disease:with special emphasis on volume, mass, and geometry / W.H.Gaasch, M.R.Zile // J. Am. Coll. Cardiol. - 2011. - Vol.58. - P.1733-1740.

15. Global Initiative for chronic obstructive lung disease - global strategy for the diagnosis, management and prevention for chronic obstructive pulmonary disease. Updated 2016.

16. Guzik T.J. "Radical” Link Between Chronic Obstructive Pulmonary Disease and Cardiovascular Disease? / T.J. Guzik, T. Grodzicki // Hypertension. - 2014. Vol. 63. - P. 444-446.

17. Impact of chronic obstructive pulmonary disease on acute phase outcome of myocardial infarction /
K. Wakabayashi, M.A. Gonzalez, C. Delhaye, I. Ben-Dor, G. Maluenda // Am. J. Cardiol. - 2010. - Vol. 106. P. 305-309.

18. Increased risk of myocardial infarction and stroke following exacerbation of COPD / G.C.Donaldson, J.R.Hurst, C.J.Smith, R.B.Hubbard [et al.] // Chest. 2010. - Vol.137. - P.1091 -1097.

19. Lahousse L. Chronic obstructive pulmonary disease and sudden cardiac death: the Rotterdam study / L. Lahousse, M.N. Niemeijer, M.E. van den Berg // Eur. Heart J. doi:10.1093/eurheartj/ehv121; Advance Access published April 28, 2015.

20. Lainscak M. Heart failure, chronic obstructive pulmonary disease, and asthma: numbers, facts, and challenges / M. Lainscak, S.D. Anker // ESC Heart Failure. - 2015. - Vol. 2 - P. 1-5.

21. Maclay D. Cardiovascular disease in COPD / D. Maclay, W. MacNee // Chest. - 2013. - Vol.143. P. $798-807$.

22. Prevalence of major comorbidities in subjects with COPD and incidence of myocardial infarction and stroke: a comprehensive analysis using data from primary care / J.R. Feary, L.C. Rodrigues, C.J. Smith, R.B. Hubbard, J.E. Gibson // Thorax. - 2010. - Vol. 65. - P. 956-962.

23. Recommendations for cardiac chamber quantification by echocardiography: an update from the American Society of Echocardiography and the European Association of Cardiovascular Imaging // J.Am.Soc. Echocardiogr. - 2015. - Vol. 28. - P. 1-39.

24. Recommendations on the use of echocardiography in adult hypertension: a report from the European Association of Cardiovascular Imaging (EACVI) and the American Society of Echocardiography (ASE) / T.H. Marwick, T.C. Gillebert, G. Aurigemma, J. Chirinos [et al.] // Eur. Heart J. Cardiovasc. Imag. - 2015. - Vol. 16. P. 577-605.

25. Rothnie K.J. Closing the mortality gap after a myocardial infarction in people with and without chronic obstructive pulmonary disease / K.J. Rothnie, L. Smeeth, E. Herrett // Heart. - 2015. - Vol. 101. - P. 1103-1110.

26. The Task Force on Myocardial Revascularization of the European Society of Cardiology (ESC) and the European Association for Cardio-Thoracic Surgery (EACTS). Guidelines on myocardial revascularization // Eur. Heart J. - 2014. -Vol.35. - P.2541 -2619.

\section{REFERENCES}

1. Dziak GV. [Effectiveness of ivabradine in patients with cardiorespiratory pathology]. Ukr. Pulmonol. Zh. 2008;3(supl.):55. Russian.

2. Dolgusheva YA, Zikov KA, Chasova IY. [B-agonists different actions in patients with combined cardiovascular pathology and bronchoobstructive diseases]. Practical pulmonology. 2015;2:41-47. Russian.

3. Koval EA. [CHF in comorbities condition: choice of optimal b-blocker]. Health of Ukraine. 2015; 3(40):19. Russian.
4. [On approval and implementation of medical and technological documents on standartization of medical care in arterial hypertention: Order N $284 \mathrm{MoH}$ of Ukraine]; 2012. Ukrainian.]

5. [On approval and implementation of medical and technological documents on standartization of medical care in stable ischemic heart disease: Order N $152 \mathrm{MoH}$ of Ukraine]; 2016. Ukrainian.

6. [On approval and implementation of medical and technological documents on standartization of medical 
care in chronic obstructive pulmonary disease: Order $\mathrm{N}$ $555 \mathrm{MoH}$ of Ukraine]; 2013. Ukrainian.]

7. Barnes PJ, Celli BR. Systemic manifestations and comorbidities of COPD. Eur. Respir. J. 2009;33:1165-85.

8. Campo G, Guastaroba P, Marzocchi A, Santarelli A, Varani E, Vignali L, Sangiorgio P, Tondi S, Serenelli C, De Palma R, Saia F. Impact of COPD on long-term outcome after ST-segment elevation myocardial infarction receiving primary percutaneous coronary intervention. Chest. 2013;144:750-7.

9. Campo G, Pavasini R, Biscaglia S, Contoli M, Ceconi C. Overview of the pharmacological challenges facing physicians in the management of patients with concomitant cardiovascular disease and chronic obstructive pulmonary disease. Eur. Heart J. - Cardiovasc. Pharmacother. 2015;1:205-11.

10. Waheed S, Chaves PHM, Gardin JM, Cao JJ. Cardiovascular and mortality outcomes in the elderly with impaired cardiac and pulmonary function: The Cardiovascular Health Study (CHS). J. Am. Heart Assoc. 2015;4:1-10.

11. Valk MJ, Broekhuizen BD, Mosterd A, Zuithoff NP, Hoes AW, Rutten FH. COPD in patients with stable heart failure in the primary care setting. Intern. J. COPD. 2015;10:1219-24.

12. van Deursen VM, Urso R, Laroche C, Damman K, Dahlström U, Tavazzi L, Maggioni AP, Voors AA. Co-morbidities in patients with heart failure: an analysis of the European Heart Failure Pilot Survey. Eur. J. Heart Failure. 2014;16:103-11.

13. Fisher KA. Impact of COPD on the mortality and treatment of patients hospitalized with acute decompensated heart failure (The Worcester Heart Failure Study): A Masters Thesis. University of Massachusetts Medical School. - GSBS Dissertations and Theses; 2014. Available from: http://escholarship.umassmed.edu/gsbs_diss/717.

14. Gaasch WH, Zile MR. Left ventricular structural remodeling in health and disease:with special emphasis on volume, mass, and geometry. J.Am.Coll. Cardiol. 2011;58:1733-40.

15. Global Initiative for chronic obstructive lung disease - global strategy for the diagnosis, management and prevention for chronic obstructive pulmonary disease. Updated; 2016.

16. Guzik TJ, Grodzicki T. "Radical" Link Between Chronic Obstructive Pulmonary Disease and Cardiovascular Disease? Hypertension. 2014;63:444-6.
17. Wakabayashi K, Gonzalez MA, Delhaye C, BenDor I, G.Maluenda G. Impact of chronic obstructive pulmonary disease on acute phase outcome of myocardial infarction. Am. J. Cardiol. 2010;106:305-9.

18. Donaldson GC, Hurst JR, Smith CJ, Hubbard RB, Wedzicha JA. Increased risk of myocardial infarction and stroke following exacerbation of COPD. Chest. 2010;137:1091-7.

19. Lahousse L, Niemeijer MN, van den Berg ME. Chronic obstructive pulmonary disease and sudden cardiac death: the Rotterdam study. Eur. Heart J. doi:10.1093/eurheartj/ehv121; 2015.

20. Lainscak M, Anker SD. Heart failure, chronic obstructive pulmonary disease, and asthma: numbers, facts, and challenges. ESC Heart Failure. 2015;2:1-5.

21. Maclay D, MacNee W. Cardiovascular disease in COPD. Chest. 2013;143:798-807.

22. Feary JR, Rodrigues LC, Smith CJ, Hubbard RB, Gibson JE. Prevalence of major comorbidities in subjects with COPD and incidence of myocardial infarction and stroke: a comprehensive analysis using data from primary care. Thorax. 2010;65:956-62.

23. Recommendations for cardiac chamber quantification by echocardiography: an update from the American Society of Echocardiography and the European Association of Cardiovascular Imaging. J.Am.Soc. Echocardiogr. 2015;28:1-39.

24. Marwick TH, Gillebert TC, Aurigemma G, Chirinos J, Derumeaux G, Galderisi M, Gottdiener J, Haluska B, Ofili E, Segers P, Senior R, Tapp RJ, Zamorano JL. Recommendations on the use of echocardiography in adult hypertension: a report from the European Association of Cardiovascular Imaging (EACVI) and the American Society of Echocardiography (ASE). Eur. Heart J. - Cardiovasc. Imag. 2015;16:577-605.

25. Rothnie KJ, Smeeth L, Herrett E. Closing the mortality gap after a myocardial infarction in people with and without chronic obstructive pulmonary disease. Heart. 2015;101:1103-10.

26. The Task Force on Myocardial Revascularization of the European Society of Cardiology (ESC) and the European Association for Cardio-Thoracic Surgery (EACTS). Guidelines on myocardial revascularization. Eur. Heart J. 2014;35:2541-619.

Стаття надійшла до редакції 08.04 .2016 